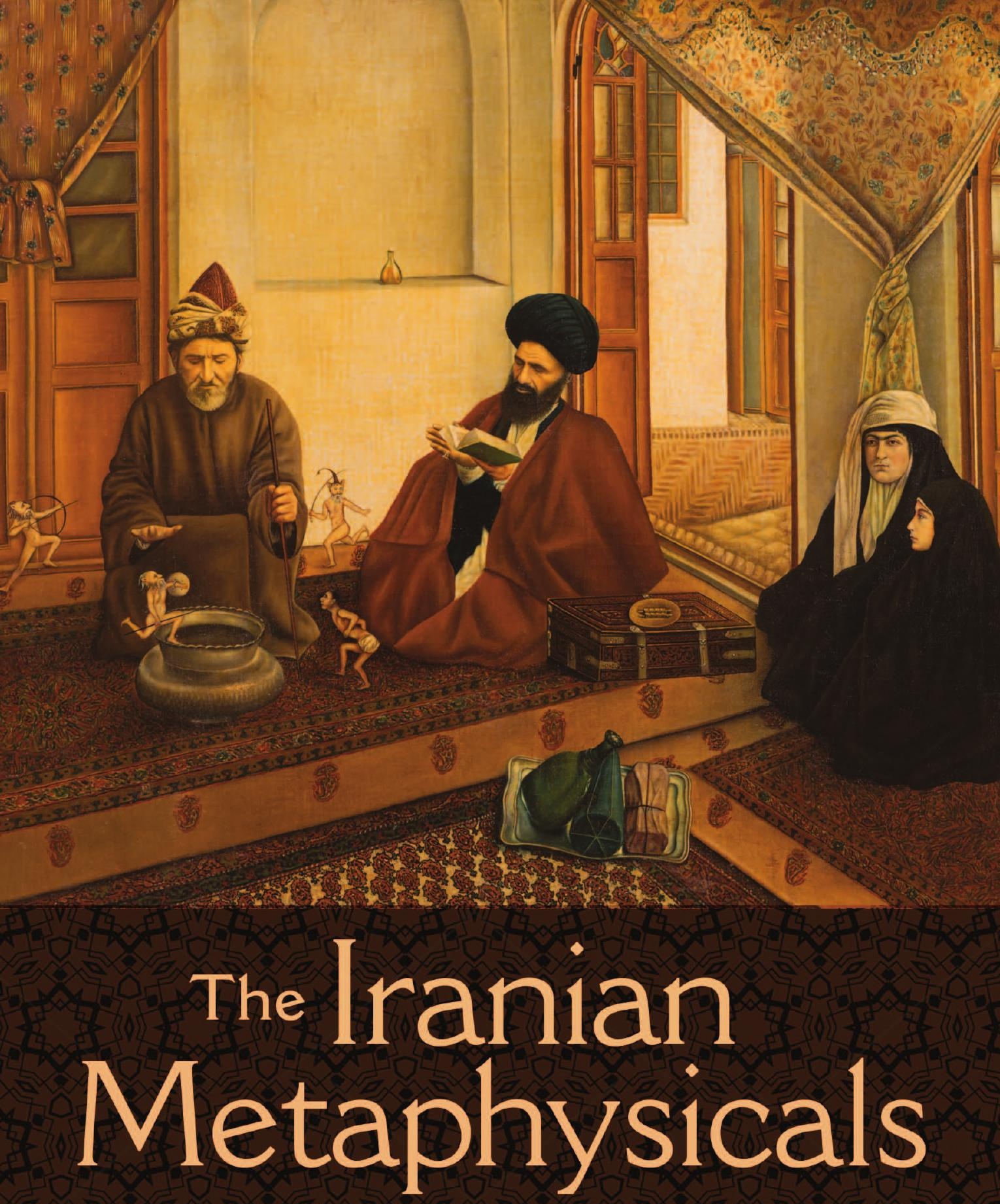

Explorations in Science, Islam, and the Uncanny

Alireza Doostdar 
THE IRANIAN METAPHYSICALS 



\section{THE IRANIAN METAPHYSICALS}

EXPLORATIONS IN SCIENCE, ISLAM, AND THE UNCANNY

\section{ALIREZA DOOSTDAR}

PRINCETON UNIVERSITY PRESS

PRINCETON AND OXFORD 
Copyright (c) 2018 by Princeton University Press

Published by Princeton University Press,

41 William Street, Princeton, New Jersey 08540

In the United Kingdom: Princeton University Press, 6 Oxford Street, Woodstock, Oxfordshire OX20 1TR

press.princeton.edu

Jacket art: Kamal ol-Mulk, Exorcist and Clients, c. 1900. Collection of Dr. Layla S. Diba. Original painting photographed by Yoav Horesh.

All Rights Reserved

Library of Congress Cataloging-in-Publication Data

Names: Doostdar, Alireza, author.

Title: The Iranian metaphysicals : explorations in science, Islam, and the uncanny / Alireza Doostdar.

Description: Princeton ; Oxford : Princeton University Press, 2018. | Includes bibliographical references and index.

Identifiers: LCCN 2017023087| ISBN 9780691163772 (hardcover : alk. paper) |

ISBN 9780691163789 (pbk. : alk. paper)

Subjects: LCSH: Islamic occultism. | Metaphysics. | Uncanny, The (Psychoanalysis) |

Mysticism-Islam. | Islam and science-Iran.

Classification: LCC BF1434.I74 D66 2018 | DDC 130.955-dc23 LC record available

at https://lccn.loc.gov/2017023087

British Library Cataloging-in-Publication Data is available

This book has been composed in Linux Libertine O and Helvetica Neue LT Std

Printed on acid-free paper. $\infty$

Printed in the United States of America

$\begin{array}{llllllllll}10 & 9 & 8 & 7 & 6 & 5 & 4 & 3 & 2 & 1\end{array}$ 
For my parents,

Sue-San Ghahremani and Hossein Doostdar, And for Elham, Hassan, Ali Sina, and Ava.

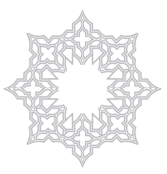


